\title{
Expanding access to secondary school education for teenage mothers in Kenya: A baseline study report
}

\author{
Chi-Chi Undie \\ Population Council \\ Harriet Birungi \\ Population Council \\ George Odwe \\ Francis Obare \\ Population Council
}

Follow this and additional works at: https://knowledgecommons.popcouncil.org/departments_sbsr-rh

Part of the Demography, Population, and Ecology Commons, Education Policy Commons, Family, Life Course, and Society Commons, Health Policy Commons, International Public Health Commons, Maternal and Child Health Commons, and the Women's Health Commons How does access to this work benefit you? Let us know!

\section{Recommended Citation}

Undie, Chi-Chi, Harriet Birungi, George Odwe, and Francis Obare. 2015. "Expanding access to secondary school education for teenage mothers in Kenya: A baseline study report," STEP UP Research Report. Nairobi: Population Council. 


\section{STEP (⿶)}

STRENGTHENING EVIDENCE FOR PROGRAMMING ON UNINTENDED PREGNANCY
KENYA

RESEARCH REPORT

DECEMBER 2015

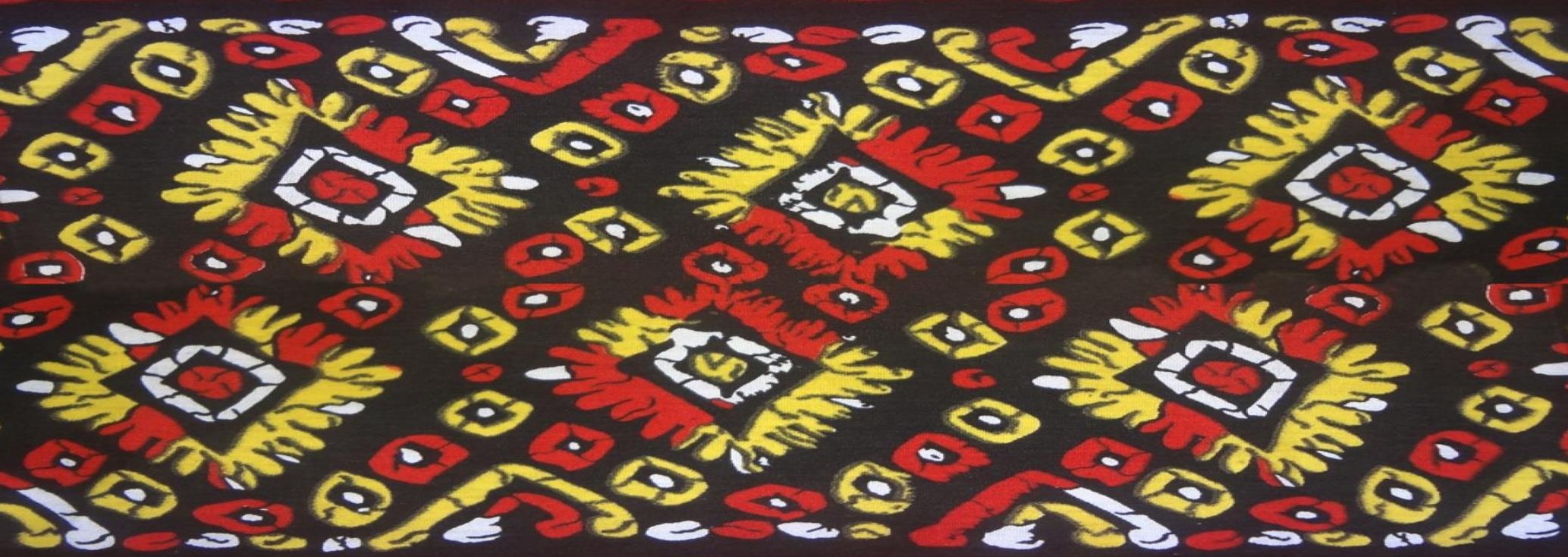

\section{Expanding Access to Secondary School Education for Teenage Mothers in Kenya: A Baseline Study Report}

CHI-CHI UNDIE, HARRIET BIRUNGI, GEORGE ODWE, FRANCIS OBARE 


\section{Expanding Access to Secondary School Education for Teenage Mothers in Kenya:}

\section{A Baseline Study Report}

CHI-CHI UNDIE, HARRIET BIRUNGI, GOERGE ODWE, FRANCIS OBARE Population Council

STEP UP RESEARCH REPORT

DECEMBER 2015

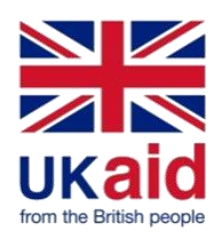


The STEP UP (Strengthening Evidence for Programming on Unintended Pregnancy) Research Programme Consortium generates policy-relevant research to promote an evidence-based approach for improving access to family planning and safe abortion. STEP UP focuses its activities in five countries: Bangladesh, Ghana, India, Kenya, and Senegal. STEP UP is coordinated by the Population Council in partnership with the African Population and Health Research Center; The International Center for Diarrhoeal Disease Research -Bangladesh (icddr-b), the London School of Hygiene and Tropical Medicine; Marie Stopes International; and Partners in Population and Development. STEP UP is funded by UK aid from the UK Government. www.stepup.popcouncil.org

\section{POPULATION COUNCIL \\ Ideas. Evidence. Impact.}

The Population Council confronts critical health and development issues-from stopping the spread of HIV to improving reproductive health and ensuring that young people lead full and productive lives. Through biomedical, social science, and public health research in 50 countries, we work with our partners to deliver solutions that lead to more effective policies, programs, and technologies that improve lives around the world. Established in 1952 and headquartered in New York, the Council is a non-governmental, non-profit organization governed by an international board of trustees. www.popcouncil.org

Suggested citation: Undie, C, Birungi, H, Odwe, G. and Obare, F. 2015. "Expanding Access to Secondary School Education for Teenage Mothers in Kenya: A Baseline Study Report," STEP UP Technical Report. Nairobi.

\section{(C) 2015 Population Council}

Please address any inquiries about STEP UP to the RPC co-directors:

Dr. Harriet Birungi, hbirungi@popcouncil.org

Dr. lan Askew, iaskew@popcouncil.org

Funded by

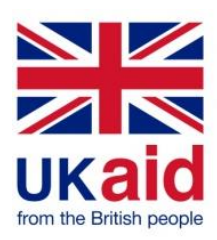




\section{Table of Contents}

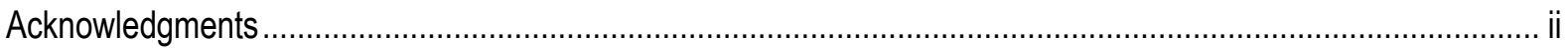

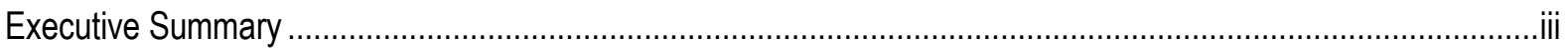

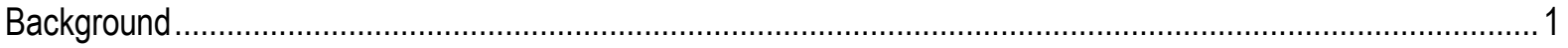

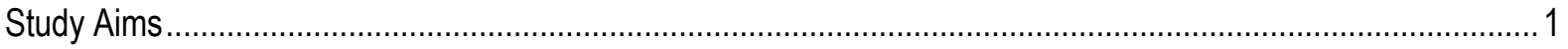

Study Design

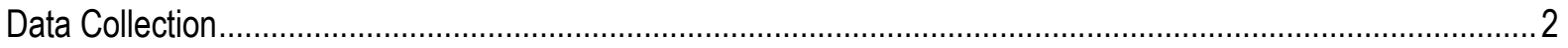

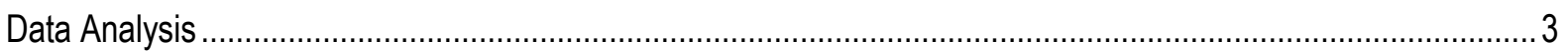

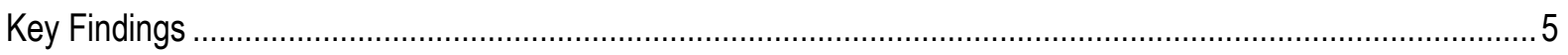

The Context of Early School-Leaving among Out-of-School Teenage Girls............................................... 5

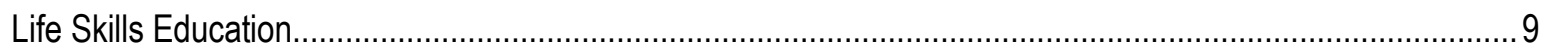

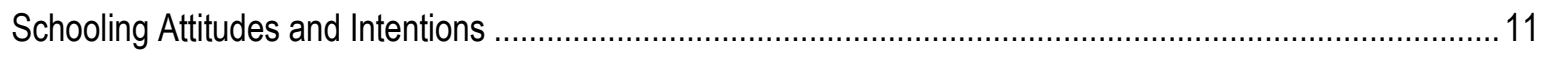

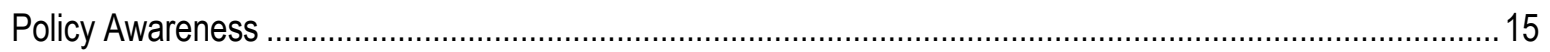

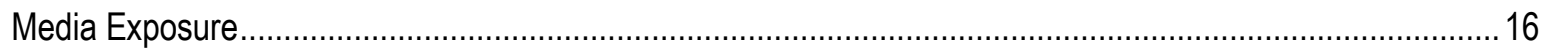

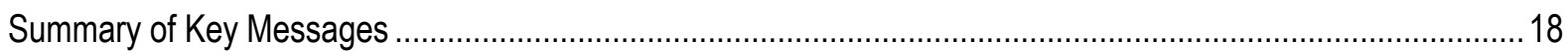

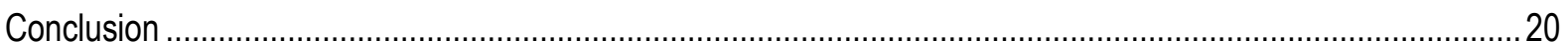

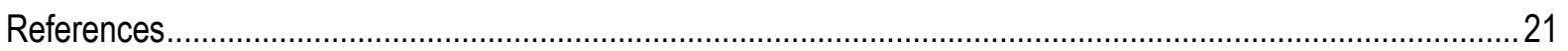




\section{Acknowledgments}

Our gratitude goes to all of the Homa Bay County respondents who took part in this study and greatly enriched our understanding of school re-entry issues in this context: teenage girls, household heads, secondary school students, and secondary school principals.

We deeply value our partnership with the Homa Bay County Department of Education, without which this study would not have been successful. We would particularly like to thank Mr. Stephen Barongo, County Director of Education; Mrs. Diosiana Ahindukha, Teachers Service Commission Director; Mr. Caleb Omondi, County Quality Assurance and Standards Officer; all sub-County Directors of Education; and all Quality Assurance and Standards Officers in Homa Bay and Ndhiwa sub-counties, for their commitment to girls and education in Homa Bay County.

Our sincere thanks go to: Jane Musia for ably handling the myriad activities that being the liaison between the Homa Bay County Department of Education and the Population Council involves; Joyce Ombeva for tireless administrative support; Janet Munyasya for carefully formatting the report; and the dedicated team of field supervisors and fieldworkers who collected all the data presented in this report. 


\section{Executive Summary}

The objectives of this study were to: 1) foster an understanding of the current situation and context in regard to out-of-school teenage mothers and their potential support systems for school re-entry at the household and school levels in Homa Bay County, 2) clarify possible solutions for promoting school re-entry on the part of outof-school girls, their families, and the education sector, and 3) provide a benchmark against which changes resulting from an intervention to promote school re-entry may be measured by the endline period.

Carried out in Homa Bay and Ndhiwa sub-counties of Homa Bay County, Kenya, the study was a baseline assessment involving the following data collection components: a household survey with out-of-school teenage girls (regardless of whether they had ever been pregnant or not) teenage mothers and their household heads; and a school survey with secondary school principals and students. This report summarizes the results of the baseline study, which was conducted from August to October 2014. Key messages emerging from the study include the following:

- Pregnancy happens early in the schooling career of most teenage girls.

- Pregnancy is often the critical incident that precedes school dropout by teenage mothers.

- Pregnancy often precipitates early marriage.

- Intimate partnerships with peers are important for understanding school pregnancy.

- School pregnancy rates are high.

- Community attitudes toward school continuation by pregnant learners or re-entry by parenting students are largely positive.

- Inconsistencies in the school and policy environments must be resolved to effectively promote school reentry.

- Most out-of-school teenage mothers would like to go back to school someday, and intend to do so.

- Financial constraints and child care are key barriers that prohibit school re-entry for teenage mothers.

- Awareness of policies that could facilitate school continuation or re-entry needs to be enhanced.

- Radio is an important means of conveying policy information to stakeholders in Homa Bay.

These findings will be used to inform the development of interventions to promote school re-entry among out-ofschool teenage mothers in Homa Bay County. The interventions will target not only out-of-school teenage mothers, but also specific populations that make up their support system at the household and school levels, including their household heads (parents/guardians and spouses), school principals, and students. Findings suggest that a media campaign centered on radio programming would be context-appropriate, and that such an avenue could be used to enhance awareness of relevant policies, as well as to garner widespread support for school re-entry by teenage mothers. It would be imperative for such a campaign to draw on key findings from this study, including those regarding the context of school dropout among teenage mothers, and information on stakeholders' attitudes and intentions around school re-entry, as well as on stakeholders' awareness of policies to promote re-entry. Employing work-related structures (e.g., policy dialogues convened by the Homa Bay County Department of Education) to reach school principals with policy messages will presumably be more effective for targeting this population. Primary school personnel must also be involved, however, given the level at which teenage mothers tend to leave school in Homa Bay County. Finally, as finances for school expenses and child care emerged as key concerns for both out-of-school teenage mothers and their household heads, future intervention designs must give attention to these issues. 


\section{Background}

This report documents baseline study findings from Homa Bay County in Kenya's former Nyanza Province as a first step toward understanding how to expand access to education for out-of-school teenage mothers. Kenya's now defunct Nyanza Province is an area characterized by high, unintended, teenage pregnancy and female school dropout rates. Nationally, levels of teenage childbearing are second highest in Homa Bay County (at 33\%), according to the 2014 Kenya Demographic and Health Survey (KNBS et al. 2015). The primary school completion rate for girls in Homa Bay County is at $54 \%$ (KNBS, 2013). Fifty-two percent of girls in this county transition to secondary school (ibid.), meaning that nearly half (48\%) are out of school. Further, $40 \%$ of girls aged 15-19 have begun childbearing.

Pregnancy and school dropout are often presumed to go hand-in-hand. Nonetheless, school dropout levels in Homa Bay County are surprising, given the education policy environment in Kenya. Kenya's school re-entry policy for girls was passed in 1994 (Republic of Kenya, 2007; Muganda-Onyango \& Omondi, 2008), and in 2009, the Ministry of Education (MOE), in collaboration with the Ministry of Public Health and Sanitation, launched the National School Health Policy (Republic of Kenya, 2009). Collectively, these policies emphasize permitting girls who become pregnant in school to continue with their education for as long as possible, and allowing pregnant learners to return to school after childbirth. This enabling policy milieu for teenage mothers calls into question the high school dropout rates among this same population.

Studies have noted that the actual implementation of school re-entry policies in Kenya requires strengthening (Wanyama \& Simatwa, 2011; Muganda-Onyango \& Omondi, 2008; Wekesa, 2011). Hardly any of these studies are based on actual interventions, however, and few available studies on school re-entry have focused on Homa Bay County. Consequently, understanding of which interventions could increase demand for education among out-of-school teenage mothers, and have a positive effect on their school re-entry practices, is still limited.

From August to October 2014, the Population Council collected baseline data in Homa Bay and Ndhiwa subcounties of the larger Homa Bay County to better understand the current situation in these sites, and to facilitate the eventual assessment of impending interventions to promote school re-entry among teenage mothers. Composed of four populations, the baseline involved: 1) a household survey of out-of-school girls aged 13-19 and their household heads, and 2) a school survey of secondary school principals and students. Summarized in this report are key findings emerging from the baseline evaluation.

\section{Study Aims}

The aims of this baseline study were three-fold: 1) to foster an understanding of the current situation and context in Homa Bay County in regard to out-of-school teenage mothers and their potential support systems for school re-entry at the household and school levels, 2) to clarify possible solutions for promoting school re-entry on the part of out-of-school teenage mothers, their families, and the education sector, and 3) to provide a benchmark against which changes resulting from an intervention to promote school re-entry may be measured by the endline period. 


\section{Study Design}

The study was a baseline assessment involving the following data collection components:

- Household survey with out-of-school teenage girls

- Household survey with household heads of out-of-school adolescent girls

- School survey with secondary school principals

- School survey with secondary school students

The study was implemented in Homa Bay and Ndhiwa sub-counties of Homa Bay County. Prior to the devolution process in Kenya, the Population Council had conducted several studies with out-of-school teenage mothers and their household heads in the corresponding areas under the then Nyanza Province. Study sites were selected in a bid to build on this earlier body of work.

\section{Data Collection}

\section{Ethical clearance}

Ethical and research clearance for this study was issued by the Institutional Review Board of the Population Council, and by the Ethics and Research Committee of Kenyatta National Hospital/University of Nairobi.

\section{Household surveys}

From September to October 2014, household surveys were carried out, facilitated by structured questionnaires which were administered by trained research assistants. A total of 728 out-of-school teenage girls (aged 13-19 years, and regardless of motherhood status) and 511 of their household heads took part in the baseline survey. Once out-of-school teenage girls' self-reported reason for no longer being in school was established during the survey, those citing pregnancy (and indicating that they had left school in the last two years preceding the survey) were asked additional sets of questions. A total of 427 out-of-school teenage mothers were asked these additional questions as part of the household survey to help better understand the context of teenage pregnancy.

Individual, written informed consent was obtained from all participants prior to conducting the interviews. The information collected included basic socio-demographic characteristics, school dropout history and context, pregnancy and childbearing experiences and intentions, schooling attitudes and intentions, awareness of and attitudes toward school re-entry policies, and access to media. Research assistants participated in a 5-day training session centered on the project goals, the content of the tools, community entry, data collection, and ethics. Pre-testing of the survey tools took place subsequent to their translation into the local language (Dholuo).

In each sub-county, a total of 100 villages were randomly sampled for inclusion in the study. All households with out-of-school girls aged 13-19 in each of the selected villages were identified with the support of Chiefs, Assistant Chiefs and village heads, and visited for interview. Those satisfying the following criteria were eligible for individual interviews:

- Female household member aged 13-19 years and out of school (In households with more than one member satisfying these criteria, all were interviewed.)

- Head of the household (male or female) regardless of age, with a female household member aged 1319 years and out of school. 


\section{School surveys}

In August 2014, and from September to October 2014, school surveys were conducted with secondary school principals and secondary school students, respectively. Individual, written informed consent/assent was obtained from all principals and students prior to conducting the interviews. In the case of students, individual, written parental consent was also obtained. Principals and students were asked questions around the basic characteristics of their individual school, school procedures for addressing school pregnancy, prevalence of pregnancy in the school concerned, awareness of and attitudes toward school re-entry policies, and access to media.

The training of research assistants was identical to that described above, albeit based on the school survey tools in particular. The school surveys for principals and students were self-administered.

All principals of public, day, co-educational ('co-ed') or girls-only secondary schools in Homa Bay and Ndhiwa sub-counties were identified in collaboration with the Homa Bay County Department of Education, and invited to participate in the study. At total of 167 school principals took part in the study.

A total of 30 public, day, co-ed and girls-only secondary schools ( 15 from each sub-county) were randomly sampled from among 64 co-ed and girls-only day schools in the two sub-counties. The sampling was stratified by the composition of the schools - i.e., girls-only day schools or co-ed day schools. The number of schools sampled in each stratum was proportional to the overall distribution of the schools in the two sub-counties - that is, $8 \%$ girls-only day schools and $92 \%$ co-ed day schools. In each school, all students in Forms 2 and 3 were invited to participate in the study. Students had to submit both parental consent and individual assent forms to be eligible for participation. A total of 1,413 secondary school students participated in the survey.

\section{Data Analysis}

Personal Digital Assistants were used to collect the household level data, which were then downloaded into ACCESS database, and analyzed using STATA. School level data were collected via hand-written, selfadministered questionnaires. These data were entered in EpiData and analyzed using STATA software. The principal procedure for data analysis involved descriptive statistics on each variable at baseline for Homa Bay and Ndhiwa sub-counties combined.

\section{Household-Level Study Populations}

The greatest proportion of out-of-school teenage girls in this study (85\%) were above the age of 15 , while only $15 \%$ were ages 13-15 (Table 1). Over a third of the corresponding household heads were aged 45 and above. Twenty-one percent of the household heads were youth aged 15-24. The household heads in this study identified themselves primarily as parents of the teenage mothers concerned $(53 \%)$, followed by as spouses $(25 \%)$. These relationships were closely corroborated by the out-of-school teenage girls, who identified their household heads as mainly being either their parents $(48 \%)$ or their spouses $(20 \%)$. It is important to note that, while the data on girls' ages in Table 1 pertains to all out-of-school teenage girls interviewed (whether they were mothers or not - i.e., $n=727$ ), the data on the girls' relationships to their household heads pertains to out-ofschool teenage mothers who left school due to pregnancy in the last two years $(n=427)$. 
Table 1: Background characteristics (Out-of-school teenage girls and household heads)

\begin{tabular}{|c|c|c|c|}
\hline \multicolumn{2}{|c|}{$\begin{array}{c}\text { Out-of-school teenage girls } \\
\text { (Percent) }\end{array}$} & \multicolumn{2}{|c|}{$\begin{array}{l}\text { Household heads } \\
\text { (Percent }\end{array}$} \\
\hline Respondent's age & $(\mathrm{N}=727)$ & Respondent's age & $(\mathrm{N}=511)$ \\
\hline 13 years & 1.2 & $15-19$ & 9.0 \\
\hline 14 years & 3.7 & $20-24$ & 11.7 \\
\hline 15 years & 10.2 & $25-29$ & 12.3 \\
\hline 16 years & 18.8 & $30-34$ & 6.7 \\
\hline 17 years & 23.7 & $35-39$ & 10.4 \\
\hline 18 years & 21.9 & $40-44$ & 12.3 \\
\hline 19 years & 20.4 & 45 and above & 36.6 \\
\hline Missing & 0.1 & Missing & 1.0 \\
\hline Relationship to household head & $(\mathrm{N}=427)$ & Relationship to teenage mother & $(\mathrm{N}=511)$ \\
\hline Parent & 47.5 & Parent & 52.5 \\
\hline Parent-in-law & 4.5 & Parent-in-law & 5.9 \\
\hline Husband & 19.7 & Husband & 24.5 \\
\hline Head of household & 7.5 & Partner (not married) & 0.0 \\
\hline Other relative & 15.5 & Other relative & 14.9 \\
\hline Other & 5.4 & Other & 2.4 \\
\hline
\end{tabular}

\section{School-Level Study Populations}

Table 2 presents the distribution of the school principals and students interviewed by gender and school type. A total of 167 head-teachers were interviewed, out of which $79 \%$ were male and $21 \%$ were female. A total of 1,413 students (52\% male and $48 \%$ female) participated in the survey. The majority of schools represented in the study were co-ed secondary schools. Only 8 percent of the schools were single-sex (girls-only) institutions.

Table 2: Background characteristics (school principals and students)

\begin{tabular}{lccccc}
\hline & \multicolumn{2}{c}{ School Principals } & & \multicolumn{2}{c}{ Students } \\
\cline { 2 - 3 } \cline { 5 - 6 } Sercent & $\mathbf{n}$ & & Percent & $\mathbf{n}$ \\
\hline Male & 79.0 & 132 & & 52.3 & 739 \\
$\quad$ Female & 21.0 & 35 & & 47.7 & 674 \\
Type of school & & & & \\
Girls-only day & 4.2 & 7 & & 7.7 & 109 \\
Co-ed day & 93.4 & 156 & & 92.3 & 1304 \\
Missing & 2.4 & 4 & & - & - \\
Total & 100.0 & 167 & & 100.0 & 1413 \\
\hline
\end{tabular}

\section{School Enrolment}

There were variations in the total number of students enrolled at each secondary school. Nevertheless, overall, more than half of the schools (59\%) had between 100 and 199 enrolled students, and just over a quarter $(26 \%)$ of the sampled schools had 200 or more enrolled students (Table 3). 


\begin{tabular}{lcc}
\hline & Percent & $\mathrm{n}=167$ \\
\hline Total number of students enrolled & & \\
Less than 100 & 15.0 & 25 \\
$100-199$ & 58.7 & 98 \\
200 and above & 25.8 & 43 \\
Missing & 0.6 & 1 \\
Number of girls enrolled & & \\
Less than 100 & 80.8 & 135 \\
$100-199$ & 18.6 & 31 \\
200 and above & 0.0 & 0 \\
Missing & 0.6 & 1 \\
Number of boys enrolled & & \\
Less than 100 & 60.3 & 94 \\
$100-199$ & 34.6 & 54 \\
200 and above & 5.1 & 8 \\
\hline
\end{tabular}

\section{Key Findings}

\section{The Context of Early School-Leaving among Out-of-School Teenage Girls}

\section{The Household Level}

The understanding of early school-leaving has often been enhanced by drawing on a framework of 'push' and 'pull' factors which could prompt this circumstance. While push factors have to do with school-based concerns (e.g., around discipline or attendance), pull factors include out-of-school inducements, such as family and work (Doll, Eslami, \& Walters, 2013). A total of 728 out-of-school teenage girls (regardless of their motherhood status) were asked what their main reason was for no longer being in school. While school dropout is understood to represent the culmination of a lengthier process of school-leaving that commenced much earlier than the date at which a student discontinues attendance (ibid.), this question referred to the critical incident which led to school dropout (or the discontinuation of attendance). When asked the main reason for their premature departure from school, the out-of-school teenage girls in this study overwhelmingly cited pregnancy $(66 \%)$, followed by the lack of school fees (23\%; Table 4). This perspective was shared by their household heads, who also cited pregnancy $(69 \%)$, followed by the lack of school fees (18\%), in comparable proportions.

Table 2: Main reason for leaving school (according to respondents' own reports)

\begin{tabular}{lcc}
\hline & $\begin{array}{c}\text { Out-of-school adolescents } \\
\mathbf{n = 7 2 7}\end{array}$ & $\begin{array}{c}\text { Household head } \\
\mathbf{n = 5 1 1}\end{array}$ \\
\cline { 2 - 3 } Pregnancy & 66.4 & 68.9 \\
Marriage & 1.9 & 2.5 \\
Lack of school fees & 22.7 & 17.6 \\
Told to repeat a class & 0.4 & 1.0 \\
Fell ill & 2.6 & 3.3 \\
To take care of sick relative & 0.1 & 0.4 \\
Completed primary & 0.6 & - \\
Completed secondary & 1.1 & - \\
Other & 4.1 & 6.3 \\
\hline
\end{tabular}


Out-of-school teenage girls who highlighted pregnancy as their main reason for leaving school were asked further questions to better understand contextual issues surrounding this circumstance. Of these, the majority $(80 \%)$ left school in their primary school years, and $88 \%$ did so two years or less before the time of interview (Figure 1). It is noteworthy that in Kenya, primary school spans an eight-year period, and students at this level, though meant to be ages 6 to 13, are often older in rural areas such as Homa Bay County.

Figure 1: Schooling level at the time of leaving school

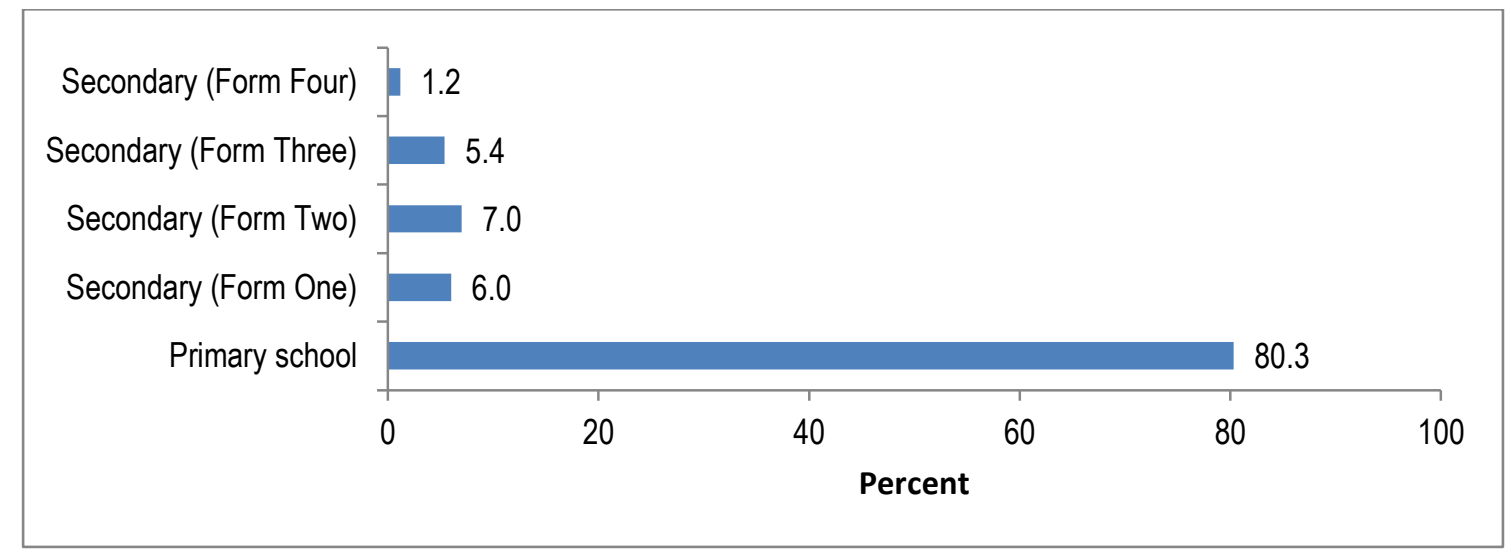

Further analysis showed that a third of the teenage mothers who pinpointed pregnancy as their main reason for being out of school, were married. When asked about their rationale for getting married, $92 \%$ of teenage mothers explained that the pregnancy that impelled their early departure from school also prompted their marriage.

The unintended pregnancy rate was found to be high among the teenage mothers interviewed. In general, those interviewed (whether married or not) had no intention of becoming pregnant at the time that they did (93\%). Most respondents ( $82 \%$ ) had had one pregnancy, versus $18 \%$ who had experienced a total of two pregnancies (Table 5). Sixteen percent were currently pregnant. Most teenage mothers (89\%) reported being impregnated by their boyfriends $-37 \%$ of whom were described as their fellow students at the time.

Table 3: Pregnancy history

\begin{tabular}{lcc}
\hline Currently pregnant & Percent & $\mathbf{n}$ \\
\hline Yes & 15.5 & 66 \\
No & 84.5 & 361 \\
Total number of pregnancies & & \\
1 & 81.8 & 346 \\
2 & 18.0 & 76 \\
3 & 0.2 & 1 \\
Person responsible for pregnancy & & 8 \\
Husband, already married to & 1.9 & 158 \\
Boyfriend (fellow student) & 37.0 & 223 \\
Boyfriend (not fellow student) & 52.2 & 1 \\
My teacher & 0.2 & 1 \\
My school principal & 0.2 & 24 \\
A boda-boda person & 5.6 & 12 \\
Other & 2.8 & \\
\hline
\end{tabular}


The literature on teenage pregnancy suggests that schools provide unsupportive environments for pregnant learners and parenting students. Indeed, stigma and discrimination by some school personnel are noted to hinder teenage mothers' demand for school re-entry (Achoka et al., 2012). Respondents who reported pregnancy as being their main reason for school dropout were asked whose decision it was for them to leave school. The vast majority $(74 \%)$ reported that leaving school was a personal decision which they came to by themselves (Table 6). Only $11 \%$ mentioned being asked to leave by their school, and a similar proportion (11\%) reported that their parents made the decision for them to drop out of school.

Table 6: Who made decision for teenage mother to leave school

\begin{tabular}{lrr}
\hline & Percent & $\mathbf{n}$ \\
\hline Myself (teenage mother) & 74.2 & 317 \\
School & 11.0 & 47 \\
Father/male guardian & 4.5 & 19 \\
Mother/female guardian & 6.6 & 28 \\
Husband & 0.5 & 2 \\
Boyfriend & 0.9 & 4 \\
Other & 2.3 & 10 \\
\hline
\end{tabular}

\section{The School Level}

\section{Pregnancy Testing}

Non-voluntary pregnancy testing in schools is regarded as a violation of school girls' rights, privacy, and dignity (UNESCO, 2014). In a bid to evade these violations, pregnant school girls may opt to drop out of school or to procure an unsafe abortion (Center for Reproductive Rights, 2013) - none of which results in positive educational or health effects. Although arguments for upholding non-voluntary pregnancy testing in schools center on the need to attend to the health needs of pregnant learners, in reality, many girls are excluded from the education system once discovered to be pregnant through such testing (Muganda-Onyando \& Omondi, 2008; UNESCO, 2014; Birungi et al., 2015). In Kenya, pregnancy testing is backed by the National School Health Policy, which prescribes 'voluntary' pregnancy testing at least once per term, although this time specification calls into question the voluntariness of this procedure.

Respondents were asked how pregnancy testing features in their schools, if at all. Forty-one percent of school principals reported that girls at their school are required to undergo an annual medical examination. Of these, nearly all (96\%) indicated that this examination includes a pregnancy test - again, raising questions about voluntariness (Table 7). A third of the principals reported that these pregnancy tests are carried out within the school premises. 
Table 7: Proportion of principals and students indicating pregnancy screening within schools

\begin{tabular}{|c|c|c|}
\hline & School Principals & Students \\
\hline & Yes (\%) & Yes $(\%)$ \\
\hline Students undergo annual medical exam & 40.7 & 44.2 \\
\hline Medical exam includes pregnancy test & 95.6 & 59.1 \\
\hline Girls screened for pregnancy at school & 32.9 & 24.1 \\
\hline
\end{tabular}

School pregnancy rates as reported by principals were notably high. A quarter of school principals observed that 5 or more girls in their school had gotten pregnant in the last one year (Figure 2). For 37\% of the principals, 3-4 girls had experienced pregnancy in the past year. Students corroborated this finding, as $21 \%$ of female students interviewed reported ever having been pregnant, and an almost similar proportion of boys - $19 \%$ - reported ever having impregnated someone (Table 8). This situation is also reminiscent of findings from out-of-school teenage mothers at the household level, over a third of whom reported being impregnated by their in-school boyfriends.

Figure 2: Number of school pregnancies in the last one year

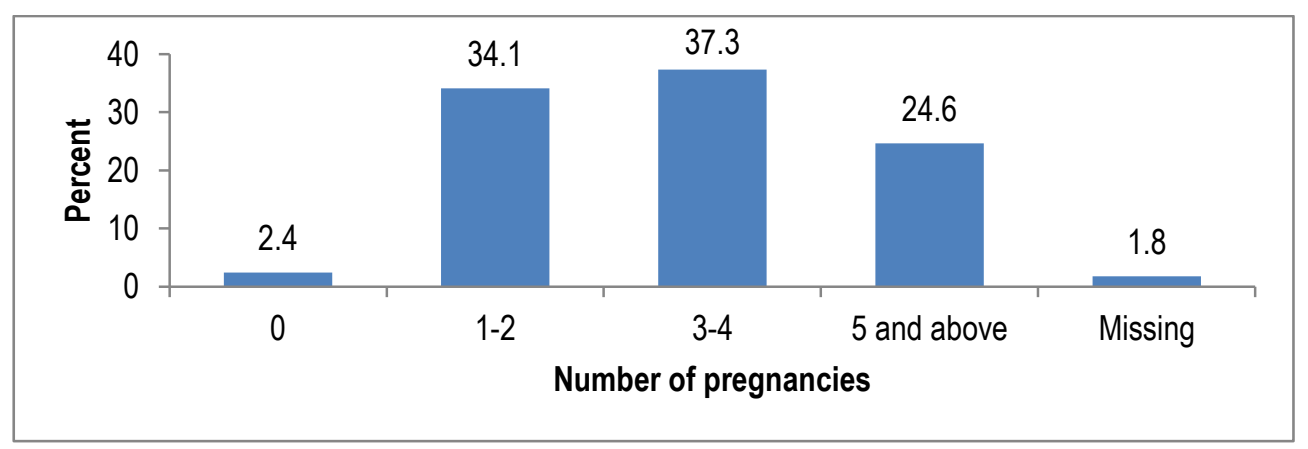

Table 8: Pregnancy history (students)

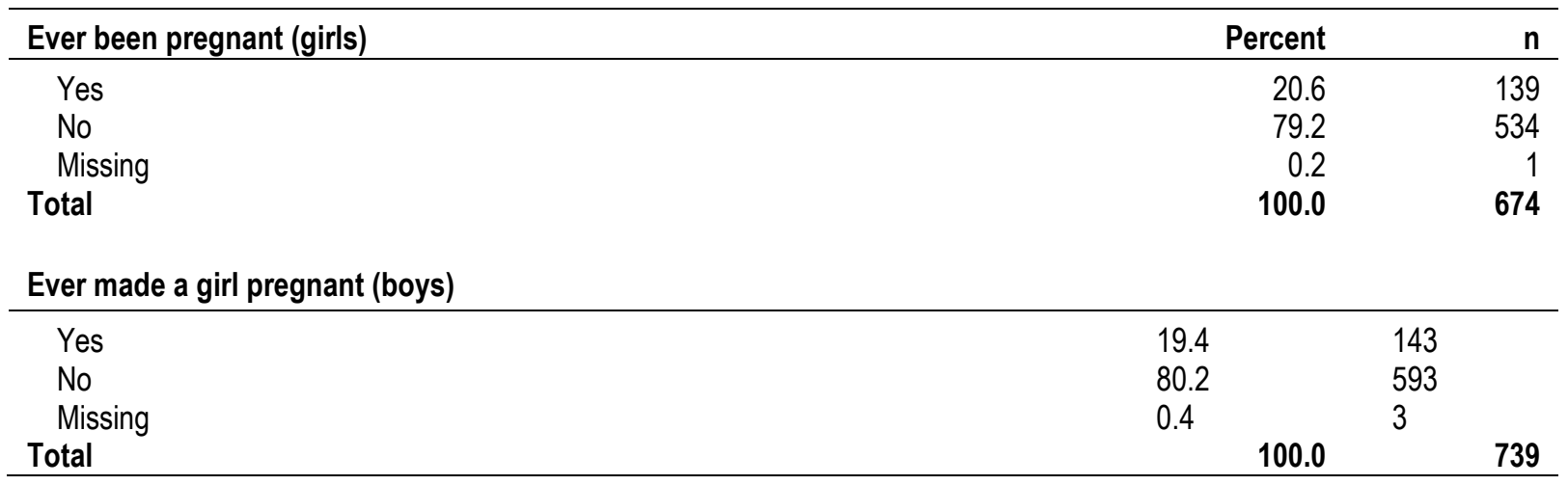

Participants were in agreement about who within their schools was responsible for monitoring school pregnancy. For principals and students alike, the Guidance and Counseling Teacher was identified as having this responsibility (52\% principals; $53 \%$ students), followed by school principals themselves (43\% principals; $26 \%$ students; Table 9). Of note is the fact that very few schools had school nurses/matrons (4\%), or counselors/psychologists/social workers (4\%), while the vast majority (87\%) had a Guidance and Counseling Teacher. 


\begin{tabular}{lcc}
\hline & School Principals (\%) & Students (\%) \\
\hline Person responsible for monitoring school pregnancy & (N=167) & (N=1413) \\
Head teacher & 42.5 & 25.7 \\
School nurse & 0.0 & 2.5 \\
School matron & 3.0 & 2.8 \\
Guidance and counseling teacher & 51.5 & 52.5 \\
Every school staff member & 38.3 & 14.1 \\
Other & 15.0 & 17.4 \\
Don't Know & - & 14.7 \\
& & \\
Actions taken when a girl is discovered to be pregnant & $(\mathrm{N}=167)$ & $(\mathbf{N}=1413)$ \\
Counseling of the girl & 74.9 & 49.3 \\
Suspension/expulsion & 9.0 & 26.0 \\
Suspension/expulsion of the boy responsible & 4.8 & - \\
Informing girl's parents & 70.7 & 32.7 \\
Referral of the girl for health care & 27.5 & 16.0 \\
Investigations into the person responsible & 35.3 & 20.0 \\
Nothing & - & 13.1 \\
Girl is given some form of punishment in school & - & 2.2 \\
Other & 10.2 & 4.8 \\
\hline
\end{tabular}

aMultiple response question.

Principals and students were not in complete agreement about the actions taken by schools when a girl is found to be pregnant. While school principals observed that counseling of the girl, informing the girl's parents, and investigations into who was responsible for the pregnancy represented the key actions, students noted that counseling, informing the girl's parents, and suspension/expulsion (mentioned by a quarter of students) were the main responses to school pregnancy (Table 9).

\section{Life Skills Education}

Given the high school pregnancy rates reported by participants, and the annual practice in place to identify school pregnancy, it is also important to understand the place of (sexuality-related) life skills education in schools, which should ideally help to prevent school pregnancy.

Comparable proportions of school principals (87\%) and students (84\%) indicated that their schools offered life skills education, or that they had ever received such lessons (not shown). A special time slot was created for life skills education in $57 \%$ of the schools, according to school principals, while $42 \%$ of schools integrated life skills education into other school subjects (Table 10). Within schools where life skills education classes existed, however, nearly half (47\%) offer this subject without a guiding curriculum, and just under half of school principals $(47 \%)$ indicated that their life skills education courses include information on contraception. 


\begin{tabular}{lll}
\hline & Percent & N \\
\hline Slot for life skills education & 57.2 & 83 \\
Own slot & 42.1 & 61 \\
Part of another subject & 0.7 & 1 \\
Missing & & \\
Life skills education provides information on contraceptives & 46.9 & 68 \\
Yes & 30.3 & 44 \\
No & 17.2 & 25 \\
Don't know & 5.5 & 8 \\
Missing & & \\
School has life skills curriculum & 49.7 & 68 \\
Yes & 46.9 & 72 \\
No & 3.5 & 5 \\
Missing & & \\
\hline
\end{tabular}

The majority of students (83\%) reported that their school does not give information on where to obtain contraception (not shown). Nonetheless, for information on pregnancy, students were most likely to report that they would go to their Guidance and Counseling Teacher (65\%), their fellow student $(19 \%)$, no one $(16 \%)$, or their school principal (10\%; Figure 3). Students (95\%) and principals (97\%) were in strong agreement about the need for schools to help girls avoid pregnancy, including having programs for this purpose (not shown).

Figure 3: Whom students would consult for information on how to avoid pregnancy

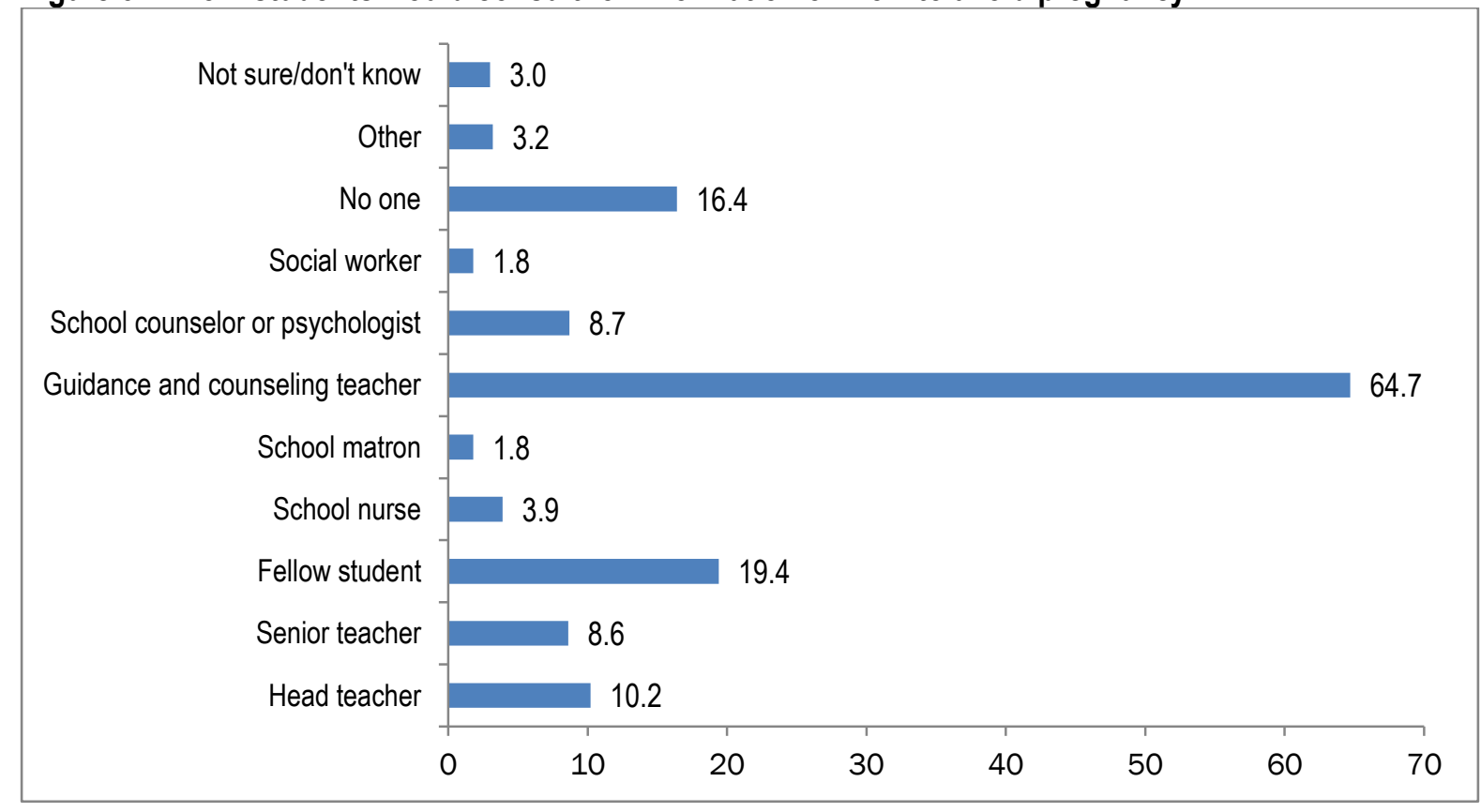




\section{Schooling Attitudes and Intentions}

\section{Attitudes}

Research points to a potential association between young people's educational intentions and their subsequent participation in education (Khoo \& Ainley, 2005). Young people's attitudes toward school and education for pregnant/parenting learners could inform not only their educational intentions, but also their schooling continuation patterns. Understanding the linkages between the attitudes and intentions of out-of-school teenage mothers is therefore important - as is understanding the attitudes and intentions of those who make up their support system.

Respondents whose main reason for leaving school was pregnancy were asked if they thought pregnant students should be allowed to remain in school for as long as they are willing and able to. An overwhelming majority (82\%) were in favor of this idea (Figure 4). Practically all respondents supported the idea of pregnant learners returning to school after childbirth (99\%).

\section{Figure 4: Opinions about school retention and re-entry}

Pregnant girls should be allowed back in school after birth

Pregnant girls should be allowed to remain in school

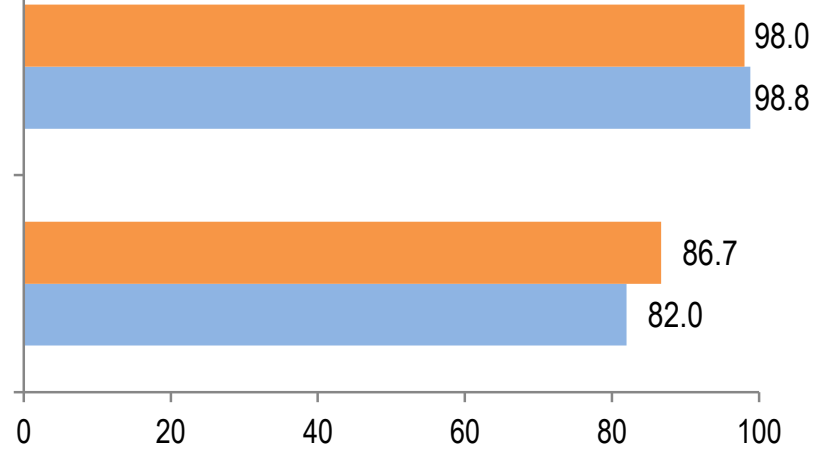

$\square$ Household heads $\quad$ Teenage mothers

Whether the issue centered on pregnant students remaining in school, or on parenting students going back to school, the main reasons for teenage mothers being in support of these practices were similar: Primarily, out-ofschool teenage mothers believed that remaining in school as a pregnant student - or returning to school as a parenting student - would permit them to improve their lives (Table 11). The other reasons were either rightsrelated ('Everyone has a right to education.') or pragmatic, upholding the view that pregnancy is not necessarily debilitating ('A girl can still learn and study when she is pregnant.'). 


\begin{tabular}{|c|c|c|}
\hline & $\begin{array}{l}\text { Retention } \\
\text { (\% yes) }\end{array}$ & $\begin{array}{l}\text { Re-entry } \\
\text { (\% yes) }\end{array}$ \\
\hline \multicolumn{3}{|c|}{$\begin{array}{l}\text { Reasons why pregnant girls should be retained in school/ allowed to re- } \\
\text { enter school after birth among teenage mothers }\end{array}$} \\
\hline a) Everyone has a right to education & 20.6 & 18.5 \\
\hline b) Allowing them will help fight stigma & 6.0 & 5.5 \\
\hline c) Allowing them will help improve their lives & 63.7 & 77.3 \\
\hline d) Allowing them will help them not to be idle & 9.4 & 5.9 \\
\hline e) Allowing them will help them feel wanted & 5.1 & 5.2 \\
\hline f) Because boys who get girls pregnant are allowed to stay & 3.4 & 1.4 \\
\hline g) A girl can still learn and study when she has a baby & 19.4 & 21.1 \\
\hline h) Other & 12.0 & 10.0 \\
\hline \multicolumn{3}{|c|}{$\begin{array}{l}\text { Reasons why pregnant girls should be retained in school/ allowed to re- } \\
\text { enter school after birth among household heads }\end{array}$} \\
\hline a) Everyone has a right to education & 18.7 & 18.8 \\
\hline b) Allowing them in school will help fight stigma/discrimination & 5.9 & 3.2 \\
\hline c) Allowing them will help improve their life and future career & 72.3 & 81.2 \\
\hline d) Allowing them will help them not to be idle & 15.4 & 11.8 \\
\hline e) Allowing them will help them feel wanted & 6.3 & 2.6 \\
\hline f) Because boys who get girls pregnant are allowed to stay & 0.5 & 0.8 \\
\hline
\end{tabular}

The attitudes of household heads, school principals, and students - i.e., community members who can potentially provide support for school re-entry by teenage mothers - were comparable to the attitudes of teenage mothers themselves. Eighty-seven percent of household heads, for instance, were of the opinion that pregnant students should be allowed to remain in school until they deliver, while $98 \%$ held the view that parenting students should be allowed to re-enter school (Table 11). Similar to out-of-school teenage mothers, household heads held these views about school retention or re-entry largely because such practices would help teenage mothers improve their lives and have future careers. This main reason was followed by opinions that 'a girl can still learn and study when she is pregnant,' and then by the rights-related belief that 'everyone has a right to education.'

Although support for the retention of pregnant and parenting learners in school was higher at the household level than at the school level, overall, there was consensus among the majority of all respondents that such learners ought to be allowed to remain in school, or to return to school after childbirth. Most respondents at the school level (whether students or school principals) were convinced that pregnant learners should be allowed to remain in school ( $69 \%$ and $71 \%$, respectively; not shown). Nearly a third of students, however, and a quarter of school principals, were unsupportive of this practice.

For students, non-support for pregnant learners remaining in school was mainly due to perceptions of pregnancy as disability ('they will not be able to concentrate on school work' - $63 \%$; 'girls who get pregnant are always sickly' $-34 \%$ ), followed by perceptions that pregnant learners in school would only serve to influence more students to get pregnant (52\%; Table 12). Among principals, non-support for pregnant learners remaining in school was overwhelmingly due to perceptions that including pregnant learners in the education system would prompt other students to get pregnant as well - a reason cited by about $80 \%$ of the school principals who did not favor the idea of pregnant girls being in school (Table 12). 
Table 6: Reasons for supporting or disapproving retention/re-entry among school principals and students

\begin{tabular}{lrr}
\hline & $\begin{array}{r}\text { School Principals } \\
\text { (\% yes) }\end{array}$ & $\begin{array}{r}\text { Students } \\
\text { (\% yes) }\end{array}$ \\
\hline Reasons for supporting retention & $(\mathbf{n = 1 1 9 )}$ & (n=972) \\
a) Everyone has a right to education & 84.9 & 71.9 \\
b) Allowing them in school will help fight stigma/discrimination & 58.8 & 25.7 \\
c) Allowing them will help improve their life and future career & 70.6 & 58.4 \\
d) Allowing them will help them not to be idle & 20.2 & 21.4 \\
e) Allowing them will help them feel wanted & 49.6 & 31.7 \\
f) Because boys who get girls pregnant are allowed to stay & 36.1 & 15.3 \\
g) A girl can still learn and study if she is pregnant/has a baby & 62.0 & 57.4 \\
h) Other & 2.5 & 1.2 \\
Reasons for disapproving retention & & \\
a) They will make other girls thinks it is good to get pregnant while still in & $(\mathbf{n}=43)$ & $(\mathbf{n}=439)$ \\
& & \\
b) Girls who get pregnant are always sickly & 79.1 & 51.7 \\
c) They will not be able to concentrate on school work & 14.0 & 33.5 \\
d) They would be mistreated/discriminated against & 32.6 & 63.3 \\
e) Their responsibilities and mothers/wives will interfere & 27.9 & 23.9 \\
f) Other & 23.3 & 21.4 \\
& 11.6 & 3.2 \\
Reasons for supporting re-entry & & \\
a) Everyone has a right to education & $(\mathbf{n}=164)$ & (n=1356) \\
b) Allowing them in school will help fight stigma/discrimination & 80.5 & 67.2 \\
c) Allowing them will help improve their life and future career & 54.9 & 22.7 \\
d) Allowing them will help them not to be idle & 76.8 & 75.3 \\
e) A girl can still learn and study if she has a baby & 23.2 & 25.7 \\
f) Because boys who get girls pregnant are allowed to stay & 65.2 & 59.0 \\
g) Other & 29.9 & 15.3 \\
\hline
\end{tabular}

As was the case with out-of-school teenage mothers and their household heads, there was almost unanimous agreement among school principals (98\%) and students (96\%) that teenage mothers should be allowed to reenter school after childbirth (not shown). The top three reasons for this stance for both principals and students were associated with beliefs in the right to education, the belief that a parenting girl could still study and learn, and that being included in the education system would help improve the lives and future careers of those concerned (Table 12).

\section{Intentions}

Under this baseline study, a total of 427 out-of-school teenage mothers who highlighted pregnancy as being the pivotal incident prompting their departure from school, were asked about their desires and intentions regarding school re-entry. The vast majority of those interviewed $(91 \%)$ reported that they would like to go back to school in the future (not shown). Furthermore, a sizeable proportion (76\%) indicated that they actually intended to return to school in the future. Indeed, $10 \%$ of teenage mothers reported that they had actually re-entered school at some point after initially dropping out. Two main reasons explain their inability to remain in the school system: the lack of finances for school expenses (52\%) and the lack of child care (18\%; Table 13$)$. 
Reasons for not remaining in school

$\begin{array}{rr}\text { Percent (yes) } & \mathbf{n} \\ & \\ 6.8 & 44 \\ 2.3 & 44 \\ 4.6 & 44 \\ 2.3 & 44 \\ 0.0 & 44 \\ 52.3 & 44 \\ 18.2 & 44 \\ 6.8 & 44 \\ 0.0 & 44 \\ 34.1 & 44\end{array}$

Reasons for not intending to resume schooling

a) Told to leave by school authorities

44

b) Got married

c) Parent/guardian did not support idea

d) Husband did not support idea

44

e) It would have been a waste of money

44

f) Lack of money for school expenses

g) No one to help with child care

h) I was being teased/gossiped about 44

j) Other

a) Told to leave by school authorities

b) Now married

c) Parent/guardian is not supportive of the idea

d) Husband is not supportive of the idea

e) It would be a waste of money

f) Lack of money for school expenses

g) No one to help with child care

h) I will be teased/gossiped about

i) I will be treated harshly by school staff

Multiple response questions.

The plans of most teenage mothers for eventual school re-entry were supported by most household heads interviewed, $87 \%$ of whom indicated that they intended to aid the teenage mother in their household in the school re-entry process (not shown). About a quarter of teenage mothers (24\%) did not intend to return to school in the future, however. Their reasons for this decision were familiar: the lack of finances for school expenses (45\%), and the lack of child care support (27\%; Table 13).

When asked what pregnant girls or young mothers need most in order to return to school, financial support for school expenses (69\%) and help with child care (47\%) emerged as the most critical needs from the perspective of out-of-school teenage mothers (Table 14). This opinion is corroborated by that of the household heads, who cited financial support for school expenses (63\%) and help with child care $(53 \%)$ as representing what out-ofschool teenage mothers need most in order to return to school.

Table 14: What pregnant girls/young mothers need to return to school

\begin{tabular}{lrr}
\hline & $\begin{array}{r}\text { Teenage mothers } \\
\text { Percent }(\mathbf{n = 4 2 7})\end{array}$ & $\begin{array}{r}\text { Household Heads } \\
\text { Percent }(\mathbf{n}=\mathbf{5 1 1})\end{array}$ \\
\hline Permission from parents/guardians & 9.8 & 13.3 \\
Permission from husbands & 4.0 & 6.9 \\
Financial support for related expenses & 68.6 & 63.0 \\
Help with child care & 46.8 & 52.8 \\
School-based child care & 3.0 & 2.9 \\
Help with finding new/different school & 8.0 & 3.8 \\
Supportive school personnel & 10.5 & 12.6 \\
Supportive students & 2.3 & 1.3 \\
Other & 12.2 & 30.4 \\
\hline
\end{tabular}




\section{Policy Awareness}

There is documentation in the literature of the linkages between education policy awareness and its effect on behavior. Studies have shown that individuals are more likely to change their behavior (or to simply behave) in accordance with the kind of policy-related information they possess (Cuevas, 2009). All participants in this study were asked questions to assess their awareness of pertinent tenets of three key education policies in Kenya: the National School Health Policy, the school re-entry policy guidelines, and the Free Secondary Education policy.

A notable feature of the National School Health Policy is its prescription that pregnant learners be allowed to 'continue with classes for as long as possible' (Republic of Kenya, 2009, p.23), in a bid to help curb school dropout. On the other hand, the school re-entry policy guidelines prescribe that pregnant learners be sent home, and supported after childbirth to re-enter the school system. Lastly, Kenya's Free Secondary Education Policy stipulates that students' tuition costs (ksh 10,265 per student in public secondary schools) are met by the government, while parents are required to cover other costs such as lunch and transportation (MOE, 2011). This reduced financial burden on parents is hoped to promote secondary school access for young people, such as out-of-school teenage mothers.

While the majority out-of-school teenage mothers and their household heads had heard that a pregnant learner was allowed to return to school after childbirth ( $93 \%$ of teenage mothers and $89 \%$ of household heads), a lower proportion were aware that pregnant learners were allowed to remain in school (according to the National School Health Policy; Figure 5). Over a third of out-of-school teenage mothers (36\%) and household heads (35\%) were not aware of this provision of the National School Health Policy. In regard to Free Secondary Education, less than half of out-of-school teenage mothers (45\%) and household heads (45\%) were aware of this policy; yet, the vast majority of teenage mothers believed that this policy would be very useful in facilitating their re-entry into school $(90 \%)$, as did their household heads ( $82 \%)$.

\section{Figure 5: Proportion that ever heard about specific school policies}

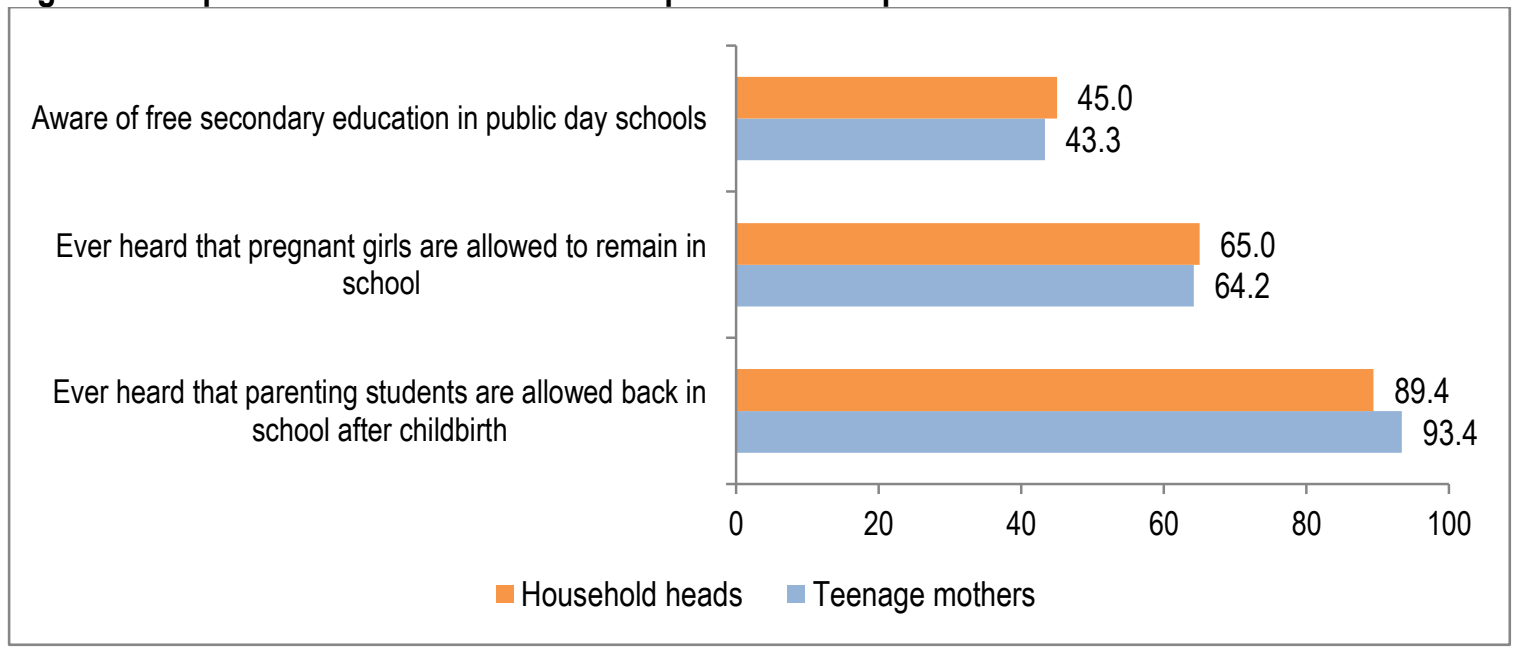

There was higher awareness of the tenets of the school re-entry policy than of the National School Health Policy at the school level, as well. Eighty-four percent of students had heard that school re-entry for a pregnant girl was permissible after childbirth; however, $44 \%$ of the same students had not heard that pregnant learners could remain in school, according to the National School Health Policy (not shown).

While the language of these policy awareness questions was simplified for teenage mothers, household heads, and students, school principals were specifically asked if they had ever heard of 'the school re-entry policy' and 'the National School Health Policy.' A third of school principals had not heard of the National School Health Policy, while $80 \%$ had heard of the school re-entry policy (not shown). 
Further questions were posed to principals to probe their knowledge of the content of these policies. Most striking with regard to the school re-entry policy was the fact that only a third of school principals were aware of their designated role (per the school re-entry policy) in supporting parenting students in identifying schools for readmission (Table 15). Furthermore, more than $60 \%$ either thought that this policy prescribed school readmission for teenage girls based on certain conditions, or were not sure, or chose not to respond to the question.

With regard to the National School Health Policy, findings show that nearly half of school principals (42\%) either believed that pregnant learners should be dismissed from school for health reasons, or were not sure, or declined to respond to this question (Table 15).

Table 15: Knowledge of content of school re-entry and National School Health policies among school principals

\begin{tabular}{|c|c|c|c|c|c|}
\hline & & True & False & Not sure & Missing \\
\hline \multicolumn{6}{|c|}{ Statements about school re-entry policy } \\
\hline \multicolumn{2}{|r|}{$\begin{array}{l}\text { a) Girls who get pregnant should receive guidance and counseling from } \\
\text { the school }\end{array}$} & 93.4 & 2.4 & 1.8 & 2.4 \\
\hline \multirow{2}{*}{\multicolumn{2}{|c|}{$\begin{array}{l}\text { b) Girls who get pregnant should be dismissed for health reasons until } \\
\text { after delivery }\end{array}$}} & & & & \\
\hline & & 16.2 & 65.3 & 7.2 & 11.4 \\
\hline \\
\hline & $\begin{array}{l}\text { admitied to otner school with some conaltions to ensure that thelr } \\
\text { behavior does not encourage other girls to engage in sexual activity }\end{array}$ & 46.1 & 36.5 & 9.0 & 8.4 \\
\hline \multicolumn{6}{|c|}{$\begin{array}{l}\text { d) Girls who dropped out of school due to pregnancy should be re- } \\
\text { admitted to other schools without conditions }\end{array}$} \\
\hline \multirow{2}{*}{\multicolumn{6}{|c|}{$\begin{array}{l}\text { e) Parents of girls who get pregnant should receive counseling from the } \\
\text { school }\end{array}$}} \\
\hline & & 67.1 & 9.6 & 12.0 & 11.4 \\
\hline f) & $\begin{array}{l}\text { Girls who get pregnant should be assisted by head teachers to get } \\
\text { admission in other schools }\end{array}$ & 34.1 & 37.1 & 15.6 & 13.2 \\
\hline \multicolumn{6}{|c|}{ Statements about National School Health policy } \\
\hline \multicolumn{5}{|c|}{$\begin{array}{l}\text { a) Girls who are pregnant should be dismissed from school for health } \\
\text { reasons }\end{array}$} & 13.2 \\
\hline b) & $\begin{array}{l}\text { Girls who get pregnant should be allowed to remain in school as long } \\
\text { as possible }\end{array}$ & 69.5 & 15.6 & 6.6 & 8.4 \\
\hline & $\begin{array}{l}\text { Girls who get pregnant can seek re-admission to the same school after } \\
\text { delivery }\end{array}$ & 83.2 & 6.0 & 5.4 & 5.4 \\
\hline & $\begin{array}{l}\text { Girls who get pregnant should be co } \\
\text { importance of antenatal care }\end{array}$ & 82.6 & 0.6 & 10.2 & 6.6 \\
\hline
\end{tabular}

\section{Media Exposure}

Radio programming played an important role in informing the policy awareness of most study participants. For example, the largest proportions of all participants learned of the school re-entry and National School Health policies on the radio (Table 16). School principals represented the sole exception to this pattern (Table 17). Over half of out-of-school teenage mothers and household heads had learned about provisions of the National School Health Policy on the radio. Similarly, just about half of both populations had heard about the school re-entry policy provisions on the radio, as well. Notably for both groups, school principals/teachers and community members were also important sources of information about these policies. 
Table 16: Main Source of education policy information for teenage mothers and household heads

\begin{tabular}{lrrrr}
\hline & \multicolumn{2}{c}{ School re-entry policy } & \multicolumn{2}{c}{ National School Health Policy } \\
\cline { 2 - 5 } & $\begin{array}{r}\text { Teenage mothers } \\
(\%)\end{array}$ & $\begin{array}{r}\text { Household } \\
\text { Heads (\%) }\end{array}$ & $\begin{array}{r}\text { Teenage } \\
\text { mothers (\%) }\end{array}$ & $\begin{array}{r}\text { Household } \\
\text { Heads (\%) }\end{array}$ \\
\hline Radio & 54.4 & 55.1 & 49.4 & 46.6 \\
Parent/guardian & 6.6 & 2.7 & 11.8 & 3.5 \\
Husband & 0.4 & 0.0 & 0.5 & 0.0 \\
School/head teacher & 33.2 & 21.7 & 32.3 & 19.3 \\
Health provider & 1.8 & 3.3 & 2.3 & 2.8 \\
Community member & 27.7 & 36.8 & 32.6 & 43.3 \\
Other & 9.9 & 22.6 & 11.0 & 26.7 \\
\hline
\end{tabular}

Radio was also a very important source of information on both policies for students (Table 17). Health facility staff members, parents, and community members were noted to play a role as informants as well, although to a lesser extent. About half of school principals learned about the policies through work-related structures, including meetings and circulars. Radio proved to be less important for getting policy information to school principals, with only $20 \%$ citing this source.

Table 17: Main source of education policy information for school principals and students

\begin{tabular}{lrlr}
\hline & $\begin{array}{r}\text { School } \\
\text { Principals } \\
(\%)\end{array}$ & Source & $\begin{array}{r}\text { Students } \\
(\%)\end{array}$ \\
\hline Source & 20.2 & a) Fellow students in school & 16.4 \\
b) Invitation letter to consultative meeting & 33.6 & b) Staff members in school & 12.6 \\
c) Government circular & 54.5 & c) Radio & 89.3 \\
d) Other Ministry of Education meeting & 56.7 & d) Parent/guardian & 21.8 \\
e) Colleagues & 19.4 & e) Someone in the community & 22.6 \\
f) Community members & 6.0 & f) Staff members in health facility & 28.6 \\
g) Other & 0.8 g) Other & 5.2 \\
\hline
\end{tabular}

The radio listening behavior of out-of-school teenage mothers and their household heads showed similar patterns. A comparable proportion of both populations reported that they ever listen to the radio ( $78 \%$ of teenage mothers and $77 \%$ of household heads; Table 18). Night time was the most popular period of the day for listening to the radio for both teenage mothers $(46 \%)$ and household heads $(66 \%)$. Further, out-of-school teenage mothers and household heads were asked if they ever listen to radio programs together. A large and similar proportion answered in the affirmative (74\% of teenage mothers; $70 \%$ of household heads). In addition, $52 \%$ of teenage mothers and $56 \%$ of household heads had heard of a radio drama about girls going back to school (not shown). 


\begin{tabular}{lrr}
\hline & $\begin{array}{r}\text { Teenage } \\
\text { mothers }\end{array}$ & $\begin{array}{r}\text { Household } \\
\text { Heads }\end{array}$ \\
\hline Ever listens to radio & $(\mathbf{n}=\mathbf{4 2 7})$ & $(\mathbf{n}=511)$ \\
Yes & 78.0 & 76.7 \\
No & 22.0 & 23.3 \\
Time of day usually listens to radio & $(\mathbf{n}=\mathbf{3 3 3})$ & $(\mathbf{n}=\mathbf{3 9 2})$ \\
Morning & 23.7 & 11.7 \\
Afternoon & 16.5 & 10.5 \\
Evening & 14.1 & 11.5 \\
Night & 45.7 & 66.3 \\
Ever listens to radio together with household head/daughter & $(\mathbf{n}=333)$ & (n=392) \\
Yes & 73.9 & 70.0 \\
No & 26.1 & 30.0 \\
\hline
\end{tabular}

\section{Summary of Key Messages}

Pregnancy happens early in the schooling career of most teenage girls

Of the out-of-school adolescent girls who highlighted pregnancy as their main reason for leaving school, $80 \%$ dropped out at the primary school level.

Pregnancy is often the critical incident that precedes school dropout by teenage mothers According to their own reports, pregnancy was the main reason why most out-of-school adolescent girls left school. This reason was cited by $66 \%$ of out-of-school teenage mothers, and was corroborated by a similar proportion of their household heads $(69 \%)$, who were mainly parents/guardians and spouses.

\section{Pregnancy precipitates early marriage}

A third of the teenage mothers who reported that pregnancy was their main reason for being out of school, were married. Of these, $92 \%$ reported that their marriage was prompted by the pregnancy that preceded their school dropout.

Intimate partnerships with peers are important for understanding school pregnancy Most teenage mothers $(89 \%)$ who noted that they were out of school due to pregnancy reported being impregnated by their boyfriends $-37 \%$ of whom were described as their fellow students at the time.

\section{School pregnancy rates are high}

A quarter of the secondary school principals noted that 5 or more girls in their school had gotten pregnant in the last one year. For $37 \%$ of the principals, 3-4 girls had experienced pregnancy in the past year. 
Community attitudes toward school continuation by pregnant learners or re-entry by parenting students are largely positive

Although larger proportions of out-of-school teenage mothers, their household heads, students, and school principals favored school re-entry for teenage mothers more than school continuation by pregnant learners, overall, attitudes towards both scenarios were largely favorable across the board.

Inconsistencies in the school and policy environments must be resolved to effectively promote school re-entry

Of the secondary schools that mandate annual medical examinations for students, nearly all (96\%) require that girls take a pregnancy test, as stipulated in the National School Health Policy. About 3 times as many students as principals indicated that girls were suspended or expelled for testing positive for pregnancy. Yet, most students reported that life skills education offered at their schools did not provide information on where to obtain contraception - and nearly all students and principals agreed that schools need to help girls prevent pregnancy.

\section{Most out-of-school teenage mothers would like to go back to school someday, and intend to do so} Of those teenage mothers who cited pregnancy as their main reason for school dropout, $91 \%$ reported that they would like to go back to school in the future, and $76 \%$ indicated that they intend to return to school someday. Sizeable proportions of their household heads have the same views and intentions.

Financial constraints and child care are key barriers that prohibit school re-entry for teenage mothers Teenage mothers opined that financial support for school expenses (69\%) and help with child care (47\%) are what they need most in order to re-enter school. This opinion was corroborated by that of their household heads, and reiterated by the few teenage mothers who had ever attempted re-entering school $(10 \%)$.

\section{Awareness of policies that could facilitate school continuation or re-entry needs to be enhanced} While the majority of out-of-school teenage mothers and their household heads were aware of the main provisions of the school re-entry policy, over a third of both groups were not aware of the provisions of the National School Health Policy (which permits pregnant learners to remain in school). An even larger proportion (nearly half) of both groups were not aware of the Free Secondary Education policy. A third of school principals were not aware of the National School Health policy, and awareness of their designated roles under the school re-entry policy was low.

\section{Radio is an important means of conveying policy information}

The largest proportions of out-of-school teenage mothers, household heads, and students learned of relevant policies on the radio. School principals learned about the policies through work-related structures. 


\section{Conclusion}

These findings will be used to inform the development of interventions to promote school re-entry among out-ofschool teenage mothers in Homa Bay County. The interventions will target not only out-of-school teenage mothers, but also specific populations that make up their support system at the household and school levels, including their household heads (parents/guardians and spouses), school principals, and students. Findings suggest that a media campaign centered on radio programming would be context-appropriate, and that such an avenue could be used to enhance awareness of relevant policies and their content, as well as to garner widespread support for school re-entry by teenage mothers. It would be imperative for such a campaign to draw on key findings from this study, including those regarding the context of school dropout among teenage mothers, information on stakeholders' attitudes and intentions around school re-entry, as well as stakeholders' awareness of policies to promote re-entry. Employing work-related structures (e.g., policy dialogues convened by the Homa Bay County Department of Education) to reach school principals with policy messages will presumably be more effective for targeting this population. Primary school personnel must also be involved, however, given the level at which teenage mothers tend to leave school in Homa Bay County. Finally, as finances for school expenses and child care emerged as key concerns for both out-of-school teenage mothers and their household heads, future intervention designs must give attention to these issues. 


\section{References}

Achoka, J.S. \& Njeru, F.M. (2012). Destigmatizing teenage motherhood: Toward achievement of Universal Basic Education in Kenya. Journal of Emerging Trends in Education Research and Policy Studies 3(6): 887-892.

Birungi, H., Undie, C., MacKenzie, I., Katahoire, A., Obare, F., \& Machawira, P. (2015). Education sector response to early and unintended pregnancy: A review of country experiences in sub-Saharan Africa. STEP UP and UNESCO Research Report.

Center for Reproductive Rights (2013). Forced out: Mandatory pregnancy testing and the expulsion of pregnant students in Tanzanian schools.

http://www.reproductiverights.org/sites/crr.civicactions.net/files/documents/crr_Tanzania_Report_Part1.pdf

Cuevas, F. (2009). Student awareness of institutional policy and its effect on peer to peer file sharing and piracy behavior. Electronic Theses, Treatises and Dissertations. Paper 2954. http://diginole.lib.fsu.edu/etd/2954/.

Doll, J.J., Elslami, Z., \& Walters, L. (2013). Understanding why students drop out of high school, according to their own reports. Are they pushed or pulled, or do they fall out? A comparative analysis of seven nationally representative studies. http://sgo.sagepub.com/content/3/4/2158244013503834

Khoo, S.T. \& Ainley, J. (2005). Attitudes, intentions, and participation: Longitudinal surveys of Australian youth, Research Report 41. Victoria, Australia: The Australian Council for Educational Research.

KNBS (Kenya National Bureau of Statistics) (2013). Homa Bay County Multiple Indicator Cluster Survey 2011, Final Report. Nairobi, Kenya: Kenya National Bureau of Statistics.

KNBS (Kenya National Bureau of Statistics), Ministry of Health (MOH), National AIDS Control Council (NACC), Kenya Medical Research Institute (KEMRI), National Council for Population and Development (NCPD), \& ICF International (2015). Kenya Demographic and Health Survey 2014. Calverton, Maryland: KNBS, MOH, NACC, KEMRI, NCPD and ICF International.

MOE (Ministry of Education) (2011). Free Day Secondary Education Programme. Nairobi: Ministry of Education.

Muganda-Onyando, R. \& Omondi, M. (2008). Down the drain: Counting the costs of teenage pregnancy and school drop-out in Kenya. Nairobi: Center for the Study of Adolescence.

Republic of Kenya (2007). Gender Policy in Education. Nairobi: Ministry of Education.

Republic of Kenya (2009). National School Health Policy. Nairobi: Ministry of Public Health \& Sanitation and Ministry of Education.

UNESCO (2014). Developing an education sector response to early and unintended pregnancy: Discussion document for a global consultation. http://unesdoc.unesco.org/images/0023/002305/230510E.pdf.

Wanyama, E.G.A. \& Simatwa, E.M.W. (2011). Prospects and challenges in the implementation of re-entry policy of girls in secondary schools in Kenya: A case study of Emuhaya District. Educational Research 2(8): 1373-90.

Wekesa, A.N. (2011). Bending the public-private gender norms: Negotiating schooling for young mothers from low-income households in Kenya. International Institute of Social Studies, Working Paper No. 515. 